ISSN 1392-3196

Zemdirbyste-Agriculture, vol. 100, No. 1 (2013), p. 81-90

UDK 633.15:631.67:520.84 / DOI 10.13080/z-a.2013.100.011

\title{
Determination of water stress with spectral reflectance on sweet corn (Zea mays L.) using classification tree (CT) analysis
}

\author{
Levent GENC ${ }^{1}$, Melis INALPULAT ${ }^{1}$, Unal KIZIL ${ }^{1}$, Mustafa MIRIK ${ }^{2}$, Scot E. SMITH ${ }^{3}$, \\ Mehmet MENDES ${ }^{1}$ \\ ${ }^{1}$ Canakkale Onsekiz Mart University \\ 17020 Canakkale, Turkey \\ E-mail: leventgc@comu.edu.tr \\ ${ }^{2}$ Texas A\&M University, AgriLife Research and Extension Center \\ 11708 Highway 70 South, Vernon, TX 76384, USA \\ ${ }^{3}$ University of Florida \\ 301 Reed Lab P.O. Box 110565 Gainesville, FL 32611-0565, USA
}

\begin{abstract}
Water stress is one of the most important growth limiting factors in crop production. Several methods have been used to detect and evaluate the effect of water stress on plants. The use of remote sensing is deemed particularly and practically suitable for assessing water stress and implementing appropriate management strategies because it presents unique advantages of repeatability, accuracy, and cost-effectiveness over the ground-based surveys for water stress detection. The objectives of this study were to 1) determine the effect of water stress on sweet corn (Zea mays L.) using spectral indices and chlorophyll readings and 2) evaluate the reflectance spectra using the classification tree (CT) method for distinguishing water stress levels/severity. Spectral measurements and chlorophyll readings were taken on sweet corn exposed to four levels of water stress with $0,33,66$ and $100 \%$ of pot capacity (PC) before and after each watering time. The results demonstrated that reflectance in the red portion $(600-700 \mathrm{~nm})$ of the electromagnetic spectrum decreased and increased in the near infrared (NIR) region (700-900 $\mathrm{nm}$ ) with the increasing field capacity of water level. Reflectance measured before the irrigation was generally higher than after irrigation in the NIR region and lower in the red region. However, when the four levels of PC and before or after irrigation only were compared, reflectance spectra indicated that water stressed corn plants absorbed less light in the visible and more light in the NIR regions of the spectrum than the less water stressed and unstressed plants. There was a similar trend to reflectance behaviour of water stress levels using chlorophyll readings that decreased over time. The $\mathrm{CT}$ analysis revealed that water stress can be assessed and differentiated using chlorophyll readings and reflectance data when transformed into spectral vegetation indices.
\end{abstract}

Key words: classification tree, spectral reflectance, water stress, Zea mays.

\section{Introduction}

Water is an important factor in agricultural and food production yet it is a highly limited resource and is becoming increasingly more important over time for optimal crop production (O'Shaughnessy et al., 2011; Wang et al., 2012). Therefore, research on irrigation and water management has focused on crop yield responses to water supply (Chen et al., 2010 a; Köksal, 2011). The use of remote sensing for irrigation practices, water resource management, and disease and insect management has been largely investigated (Ozdogan, 2011; Elmetwalli et al., 2012). The spectral characteristics of healthy vegetative surfaces are distinctive with low reflectance in blue, high in green, very low in red and very high in the near infrared (NIR). The overall reflectance of water in the visible region $(400-700 \mathrm{~nm})$ is relatively low and in the NIR (700-900 $\mathrm{nm})$ it is practically zero (Rock et al., 1986; Gitelson, Merzlyak, 1996; Sims, Gamon, 2002). Extensive research has been conducted to study pigment concentration of plants using spectral reflectance under various environmental conditions and stresses (Blackburn, 2007).

A large number of vegetation and water indices has been developed to measure plant vigour and other biophysical parameters using remotely sensed data (Rodríguez-Pérez et al., 2007; Chen et al., 2010 b; Elsayed et al., 2011). Hunt and Rock (1989) indicated that leaf water content index measures leaf relative water content directly and can be used to determine when 
certain plant species with different leaf morphologies are water stressed. Rodríguez-Pérez et al. (2007) reported that noninvasive monitoring using hyperspectral vegetation indices could improve current traditional methods for estimating water status of individual vines. Spectral vegetation indices were designed to evaluate vegetation condition, foliage, cover, phenology and processes in addition to be used for land cover classification, climate and land use detection, drought monitoring and habitat loss (Padilla et al., 2011) More recently, Mirik et al. (2012) discussed that spectral vegetation indices are mathematical expressions involving reflectance values from different part of the electromagnetic spectrum, aimed to optimize information and normalize measurements made across varied environmental conditions. Varied environmental conditions include differences in plant species, solar angle, shadowing, illumination, canopy coverage, soil background, atmospheric condition and viewing geometry of the device over space and time.

Since there are many water absorption and reflection features in the red and NIR parts of the electromagnetic spectrum, analysis of spectral reflectance has resulted in several useful water indices (Serrano et al., 2000). A few water indices developed to study crop stress include the water band index (WBI) proposed by Peñuelas et al. (1993), shortwave infrared water stress index (SIWSI) developed by Fensholt and Sandholt (2003), and normalized difference water index (NDWI) of Gao (1995) and Serrano et al. (2000). In addition to these indices, some of the other vegetation indices or spectral waveband ratios are also important indicators to determine and detect water stress in vegetation.

In addition to vegetation indices, many statistical and mathematical models such as principle component analysis (Genc, 2003), random forest, support vector machine, artificial neural network, and other classification procedures have been developed to extract optimal information from remotely sensed data. Classification tree (CT) was developed to investigate the relationship between the categorical data and determine the variables affecting other independent variables (Yohannes, Hoddinott, 1999). Researchers observed that the CT was a very useful model to analyze complex data sets by providing visual results (Camdeviren et al., 2005).

Several researchers discussed that remote sensing removes human bias in visual stress severity evaluation that can be highly variable among individuals. In addition, remote sensing is a better method to detect and quantify the impact of plant stress compared to visual techniques because a vegetative unit can be repeatedly, objectively, and nondestructively examined in a fast, robust, accurate, and inexpensive way (Mirik et al., 2006; 2012; Elsayed et al., 2011). The objectives of our study were 1) to examine the use of spectral reflectance characteristics and chlorophyll readings to discern water stress severity imposed with four irrigation levels $(0,33$, 66 and $100 \%$ of pot capacity (PC) on sweet corn (Zea mays L.) grown in controlled conditions and 2) to explore the effectiveness of $\mathrm{CT}$ for discriminating water stress severity using spectral indices before and after irrigation.

\section{Materials and methods}

Experimental design. Sweet corn ('Merit F1') was planted into pots containing a mixture of field soil and turf with a $\mathrm{pH}$ of 7.2 as the growth medium on November 27, 2007 and harvested on February 11, 2008 in this research. The experiment was designed by using four sets of potted plants with three replicates. Six litre pots were stored in the controlled laboratory at $26-28^{\circ} \mathrm{C}$ and $60-70 \%$ relative humidity with a $16: 8$ hour photo period. Four watering levels were designed by controlling soil water contents at 0 (no irrigation), 33, 66 and 100\% (full irrigation or control) of pot capacity (PC). In the beginning, all pots were watered to the PC to facilitate uniform germination. All pots were weighed and watered nine times during the period from November 27, 2007 to February 11, 2008 to base on the designed water levels. Watering periods were 14, 21 and 28 December 2007, 4, 11, 18 and 25 January 2008, 1 and 8 February 2008. During the experiment, water was added to 0 (no irrigation), 33, 66 and $100 \%$ PC pots as $0,1.92,3.67$, and $6.10 \mathrm{~L}_{\text {per }}$ pot $^{-1}$, respectively.

Chlorophyll and spectral measurement. In this study, leaf chlorophyll content was measured using a hand-held chlorophyll meter "Fieldscout CM1000" ("Spectrum Technologies Inc.", USA) and spectral data was collected using "FieldSpect" hand-held field spectroradiometer ("Analytical Spectral Devices Inc.", USA). The spectroradiometer was equipped with a $10^{\circ}$ field of view. Spectral reflectance was obtained from three different parts on the same leaf. In each location of selected leaf, five readings were taken that were automatically averaged and reported. Spectral reflectance were measured before and 72 hours after irrigation. The first measurement was made 10 days after sowing (December 7). The measurements for before irrigation from individual pot were made and used to determine spectral indices as follow: 14 and 28 December 2007, 11 and 25 January 2008 and 8 February 2008. The measurements after irrigation were made as follows: 17 and 31 December 2007, 14 and 28 January 2008 and 11 February 2008 which was at the end of the experimental period (76 days after sowing). The spectroradiometer was calibrated with a plate made of barium sulphate before each measurement. A halogen light, $15 \mathrm{~V}$ and 4.6 $\mathrm{A}$, at a 45 degree angle was used as the energy source to measure leaf reflectance and chlorophyll readings. Chlorophyll readings and spectral measurements were taken from the three parts of the same leaves. Using the reflectance data, five vegetation indices were computed and used to distinguish water stress severity in CT model. Vegetation indices and ratio of wavebands used in this study are provided in Table 1 .

Statistical analysis. The CT method described in detail by Lewis (2000) was used to differentiate the water stress using the following formula:

$$
\frac{C(j / i) \pi_{i} N_{i}^{(t)}}{C(i / j) \pi_{j} N_{j}^{(t)}}>\frac{N_{i}}{N_{j}} \text { is satisfied for all the }
$$

values of $j(j=1,2, \ldots, k$ and $j \neq i)$, 
where $\mathrm{C}(j / i)$ - cost of classification of class $i$ as if class $j$ (coefficient of the risk matrix), $\pi_{i}$ - prior probability of the class $i, \mathrm{~N}_{i}-$ number of the experiment units in $i$ class in the learning sample.

Table 1. Spectral indices and ratio of spectral wavebands used to differentiate water stress in sweet corn

\begin{tabular}{cccc}
\hline Index & Abbreviation & Formula & Reference \\
\hline Normalized difference vegetation index & NDVI & (NIR - R) / (NIR + R) & Rouse et al. (1973) \\
Green NDVI & GNDVI & (NIR - G) / (NIR + G) & Gitelson, Merzlyak (1996) \\
Simple ratio & SR & R / NIR & Jordan (1969) \\
Ratio between blue and NIR & BN & B / NIR & this study \\
Ratio between green and NIR & GN & G / NIR & this study \\
Ratio between red + green and NIR & RGN & (R + G) / NIR & this study \\
\hline
\end{tabular}

NIR - reflectance in near infrared, $\mathrm{R}$ - reflectance in red, $\mathrm{G}$ - reflectance in green, $\mathrm{B}$ - reflectance in blue regions of the spectrum

\section{Results and discussion}

Chlorophyll. The chlorophyll readings decreased after irrigation for all dates when samples were taken as illustrated in Figure 1. We observed that chlorophyll readings of sweet corn under water stress with $0 \%$ and $33 \%$ PC were also less than those of $66 \%$ and $100 \%$ PC. It appears that chloroplast concentration increases in stressed plants relative to unstressed plants. We found that chlorophyll readings decrease as the corn approaches the maturity.

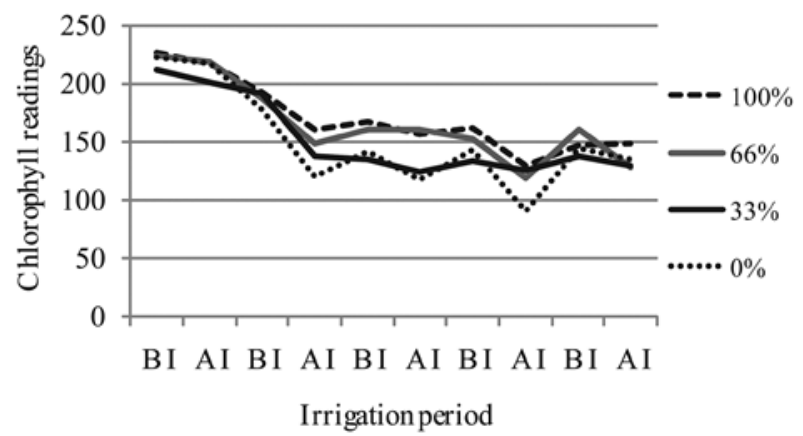

Figure 1. Comparison of water stress level and chlorophyll concentration before irrigation $(\mathrm{BI})$ and after irrigation (AI)

The presence of a disease, insect feeding or deficiency in growth limiting factors such as water stress leads to change in chemical-pigment concentrations, leaf area, and cell structure of the affected plant tissues (Mirik

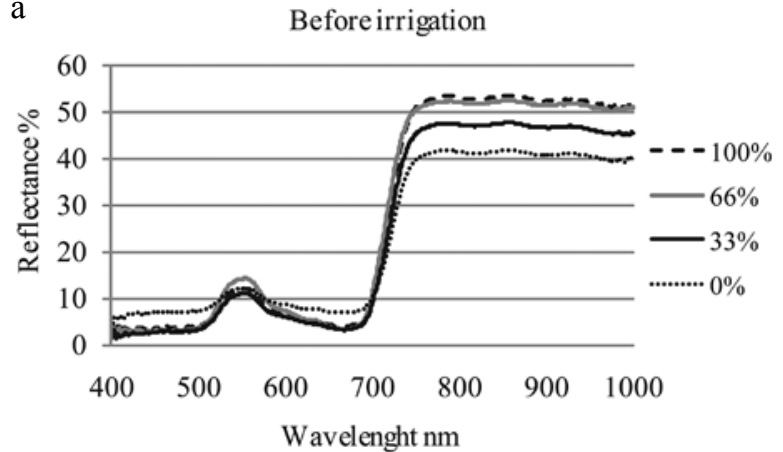

et al., 2012). A decrease in chlorophyll amount from water stressed plants provided evidence that water deficiency degraded the photosynthetic pigments and changed the leaf morphology in corn canopies. Elsayed et al. (2011) reported that water deficiency causes alteration in leaf pigment composition, concentration, and cell structure by changing the properties of connections between air spaces and cell walls, cell wall composition and structure or cell size and shape. It is apparent in our study that observed reductions of chlorophylls in $0 \%$ and $33 \%$ PC were as a result of water stress. Leaf chlorophyll content decreases in water stressed plants (Govender et al., 2009). The authors also indicated that reduced chlorophyll content in plants is directly related to water stress leading to change in chlorophyll to carotenoid and chlorophyll $a$ to chlorophyll $b$ ratios that are an indicator of water stress. Alberte et al. (1977) found that the majority of chlorophyll lost in response to water stress occurred in the mesophyll cells with a lesser amount being lost from the bundle sheath cells. Increasing severity of water stress clearly reduced the photochemical activity of chlorophyll, absorption of nutrients by corn roots, and nutrient transportation from root to shoots (Elmetwalli et al., 2012).

Spectral analysis. After investigating spectral reflectance of corn leaves, it was found that reflectance values from all dates showed similar pattern. Since all reflectance values showed similar pattern, January 11 when spectral measurement was made before irrigation and January 14 when spectral measurement was made after irrigation were further investigated (Figs 2 and

b

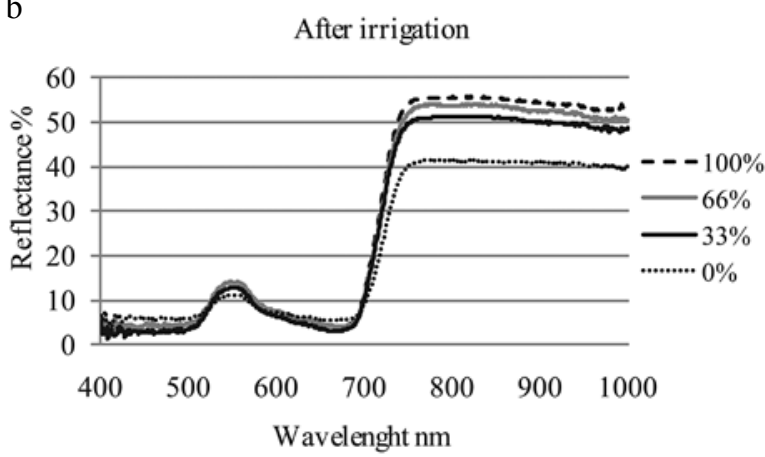

Figure 2. The average values of spectral reflectance from sweet corn in January 11 before irrigation (BI) and January 14 after irrigation (AI): a) BI at all field capacities, b) AI at all field capacities 
3). Spectral reflectance of corn varied with water stress levels and changed before and after irrigation (Fig. 2 a and $b$ ). Before irrigation, the reflectance of corn in the NIR region decreased with decreasing irrigation levels (Fig. 2 a). After irrigation, spectral measurement showed that the reflectance of corn increased for $33 \%, 66 \%$ and $100 \%$ irrigation level compared to before irrigation (Fig. $2 \mathrm{~b})$. There was no noticeable change for $0 \%$ water levels before and after irrigation. Before irrigation, in the visible region of the spectrum, the reflectance was slightly higher and stayed very close in the NIR region for $0 \% \mathrm{PC}$ when compared to measurements made after irrigation as

a

Field capacity $=0 \%$

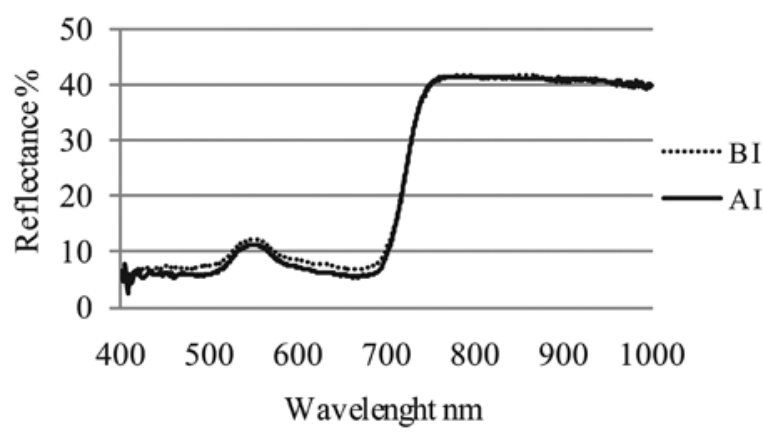

b Field capacity $=33 \%$

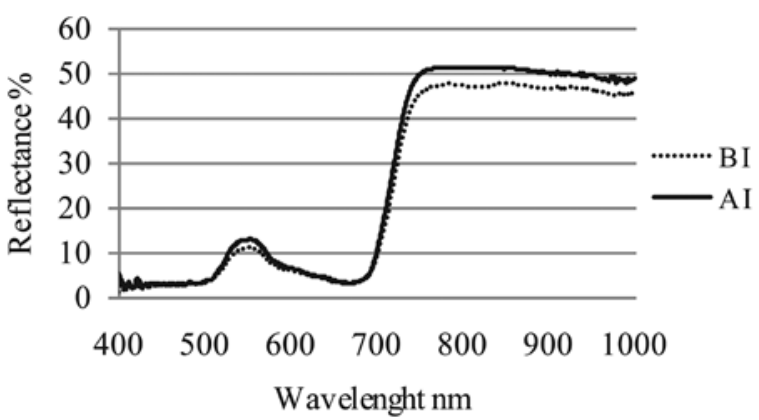

shown in Figure 3 a. When water amount increased from $0 \%$ to $33 \%$ PC, the reflectance between 500 and $600 \mathrm{~nm}$ and in the NIR around $750 \mathrm{~nm}$ after irrigation was higher than that of before irrigation, while the reflectance in the remaining portions of the spectrum was close to each other (Fig. 3 b). When watering level was increased from $33 \%$ to $66 \%$ PC, reflectance trend changed slightly less before irrigation than after irrigation (Fig. $3 \mathrm{c}$ ) in the visible region from 400 to $500 \mathrm{~nm}$ and the NIR region from 750 to $900 \mathrm{~nm}$. Increasing water level from $66 \%$ to $100 \% \mathrm{PC}$, there was a trend in reflectance that was very similar to what we observed for 33\% PC (Fig. $3 \mathrm{~d}$ ).
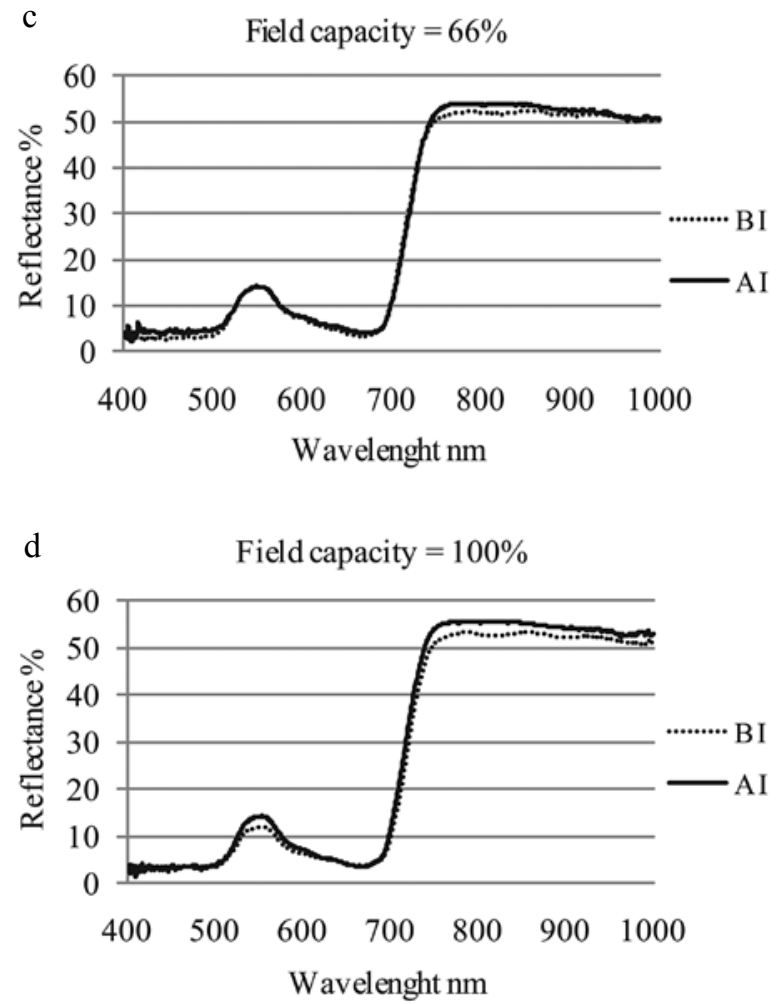

Figure 3. The average values of spectral reflectance from sweet corn: a) comparison of spectral reflectance before and after irrigation for $0 \%$ field capacity, b) comparison of spectral reflectance before and after irrigation for $33 \%$ field capacity, c) comparison of spectral reflectance before and after irrigation for $66 \%$ field capacity, d) comparison of spectral reflectance before and after irrigation for 100\% of field capacity in January 11 (BI) and January 14 (AI)

For all water application levels, reflectance values between 550 and $800 \mathrm{~nm}$ before irrigation were higher than after irrigation except for the $680 \mathrm{~nm}$ where reflectance values before irrigation were lower than after irrigation. This demonstrates that the chlorophyll content of the corn leaves was higher before irrigation than after irrigation. Reflectance at water sensitive wavebands (940-970 nm) before irrigation was slightly higher than after irrigation. When only before or after irrigation for four levels of PC compared, unstressed corn plants with increasing level of water deficiency (e.g., 33\% PC) had lower reflectance in the visible spectrum and higher reflectance in the NIR region of the spectrum than those of unstressed plants (100\% PC).

We observed that these results in the visible and NIR regions of the spectrum were closely agreed with the findings of other studies reported earlier. In this region, water stressed corn had higher reflectance than unstressed corn in the visible spectrum in contrast to much higher reflectance from unstressed plants when compared to lower reflectance from stressed plants in the NIR spectrum (Elmetwalli et al., 2012). Elmetwalli et al. (2012) also observed that water stressed wheat (Triticum aestivum L.) canopy had higher reflectance in the visible region and lower reflectance in the NIR regions when compared to unstressed wheat canopy. Weber et al. (2012) observed similar response of water stressed corn to those of Elmetwalli et al. (2012) and our study. Our results were slightly different from those of Elmetwalli et al. (2012) that water stressed plant could not quickly enough respond to watering to recover. Another reason for difference is that Elmetwalli et al. (2012) conducted 
their study at canopy scale, whereas our study was conducted at leaf level or corn varieties used in both studies. The slight difference in reflectance values before and after irrigation at four PC are most likely related to short watering time period when spectra were measured that stressed corn plants could not take advantage of watering to recover. The change in leaf morphology and leaf pigment concentrations and amount have a strong influence on leaf spectral properties. Water induced stress in corn leaves resulted in optical differences between stressed and unstressed plants. Apparently, the reduction in pigment concentrations, in addition to change in leaf morphology induced by deficiency in water availability caused higher reflectance in the visible spectra between stressed and unstressed corn leaves and before and after watering at four watering treatments. Symptoms due to water deficiency, in addition to leaf senescence, were often related to the decrease in NIR reflectance spectra. In the present study, lower reflectance spectra in the NIR region from stressed leaves when compared to lesser stress or unstressed corn leaves indicate that water stress also reduced green leaf area.

\section{Classification tree analysis. Before irrigation.}

In order to determine the water stress severity before irrigation, normalized difference vegetation index (NDVI), green normalized difference vegetation index (GNDVI), $\mathrm{red} / \mathrm{NIR}(\mathrm{RN})$, blue/NIR (BN), green/NIR (GN), and red + green/NIR (RGN) were investigated in CT paths (Fig. 4). The $\mathrm{CT}$ analysis revealed that classification accuracy for before irrigation was $63.1 \%$ (Table 2).

Table 2. Classification accuracy between observed and predicted values for sweet corn grown under four levels of water treatment before irrigation

\begin{tabular}{cccccc}
\hline \multirow{2}{*}{ Observed } & \multicolumn{5}{c}{ Predicted } \\
\cline { 2 - 5 } & \multicolumn{5}{c}{ irrigation level } \\
\cline { 2 - 5 } & 0 & 33 & 66 & 100 & $\%$ \\
\hline 0 & 14 & 1 & 3 & 3 & 66.7 \\
33 & 3 & 13 & 3 & 2 & 61.9 \\
66 & 3 & 2 & 14 & 2 & 66.7 \\
100 & 3 & 3 & 3 & 12 & 57.1 \\
Overall correct \% & 24.4 & 22.6 & 27.4 & 22.6 & 63.1 \\
\hline
\end{tabular}

Among the indices, CT model selected GNDVI as a starter index to predict the water stress (Fig. 4). It was calculated that there was no water stress in $63.2 \%$ of the plants when GNDVI was $\leq 0.5509$ and GN was $\geq 0.1446$ in full irrigation. On the other hand, if the GN was smaller than 0.1446 , the chlorophyll readings must be taken into consideration to understand the water stress levels. Severe water stress could be expected in $60.0 \%$ of the plants at no irrigation level $(0 \% \mathrm{PC})$ if chlorophyll reading was $\leq 174.5$. In contrast, water stress was not expected at $66 \% \mathrm{PC}$ if chlorophyll reading was $\geq 174.5$ in full irrigation (Fig. 4).

For further water stress determination, the other branch of the CT was examined. It was investigated that when GNDVI value was $>0.5509$ and chlorophyll value was $<158.4$, severe water stress could be expected in $62.5 \%$ of plants at no irrigation pots. Similarly, when the chlorophyll value was higher than 158.4 , additional indices or spectral ratios such as $\mathrm{BN}, \mathrm{RN}$ and $\mathrm{RGN}$ were taken into account to determine water stress in corn. In this study, when chlorophyll value was $>158.4$, BN ratio should be considered to determine whether water stress existed or not. When $\mathrm{BN}$ value was $>0.6350$ water stress was not expected because all the values for BN fell into $66 \%$ treatment (Fig. 4). As the BN value was $\leq 0.635$, moderate water stress $(51.9 \%$ of the plants) was projected at $33 \%$ water treatment. Furthermore, there was moderated water stress while $\mathrm{BN}$ value was $\leq 0.635$ and RN value was $>0.1625$ (Fig. 4). However, when $R N$ value was $\leq 0.162$, RGN was an indicator to investigate further whether water stress existed or not. When RGN value was $\leq 0.2546$, water stress was not expected $(75.0 \%)$. Under the same level of irrigation, when RGN value was $>0.2546$, a severe water stress could be expected (54.5\%) (Fig. 4).

After irrigation. Classification accuracy after irrigation was fount as $65.5 \%$ (Table 3 ).

Table 3. Classification accuracy between observed and predicted values for sweet corn grown under four levels of water treatment after irrigation

\begin{tabular}{|c|c|c|c|c|c|}
\hline \multirow{3}{*}{ Observed } & \multicolumn{5}{|c|}{ Predicted } \\
\hline & \multicolumn{4}{|c|}{ irrigation level } & \multirow{2}{*}{$\begin{array}{c}\text { correct } \\
\%\end{array}$} \\
\hline & 0 & 33 & 66 & 100 & \\
\hline 0 & 18 & 2 & 0 & 1 & 85.70 \\
\hline 33 & 8 & 12 & 0 & 1 & 57.10 \\
\hline 66 & 6 & 5 & 7 & 3 & 33.30 \\
\hline 100 & 2 & 1 & 0 & 18 & 85.70 \\
\hline Overall correct $\%$ & 40.50 & 23.80 & 8.30 & 27.40 & 65.50 \\
\hline
\end{tabular}

It was observed that GNDVI was the main indicator to determine the water stress in corn plant as was before irrigation (Fig. 5). There was no water stress in $100 \%$ of the plants when GNDVI value was $<0.6304$ and NDVI values were $>0.8020$. Figure 5 shows that when NDVI was $\leq 0.8020$, GN was an effective index for remote detection of water stress. When GN value was $>0.2550$, we found that there was no water stress in $85.7 \%$ of the corn plants at $66 \%$ and $100 \%$ PC. When the GN value was $<0.2550$, the chlorophyll levels of these plants led to remote assessment of water stress. Severe water stress could be expected in $54.5 \%$ of the plants at no irrigation pots $(0 \% \mathrm{PC})$ when chlorophyll reading value was $\leq 186.1$. In contrast, water stress was not projected at $66 \% \mathrm{PC}$ and full irrigation pots when chlorophyll reading was $\geq 186.1$ (Fig. 5).

In order to further determine water stress levels, the second branch of the CT was examined (Fig. 5). When GNDVI was $>0.6304$ and GN was $>0.1956$, severe water stress could be projected in $52.2 \%$ of plants at no irrigation pots. When the GN value was $>0.1956$, 


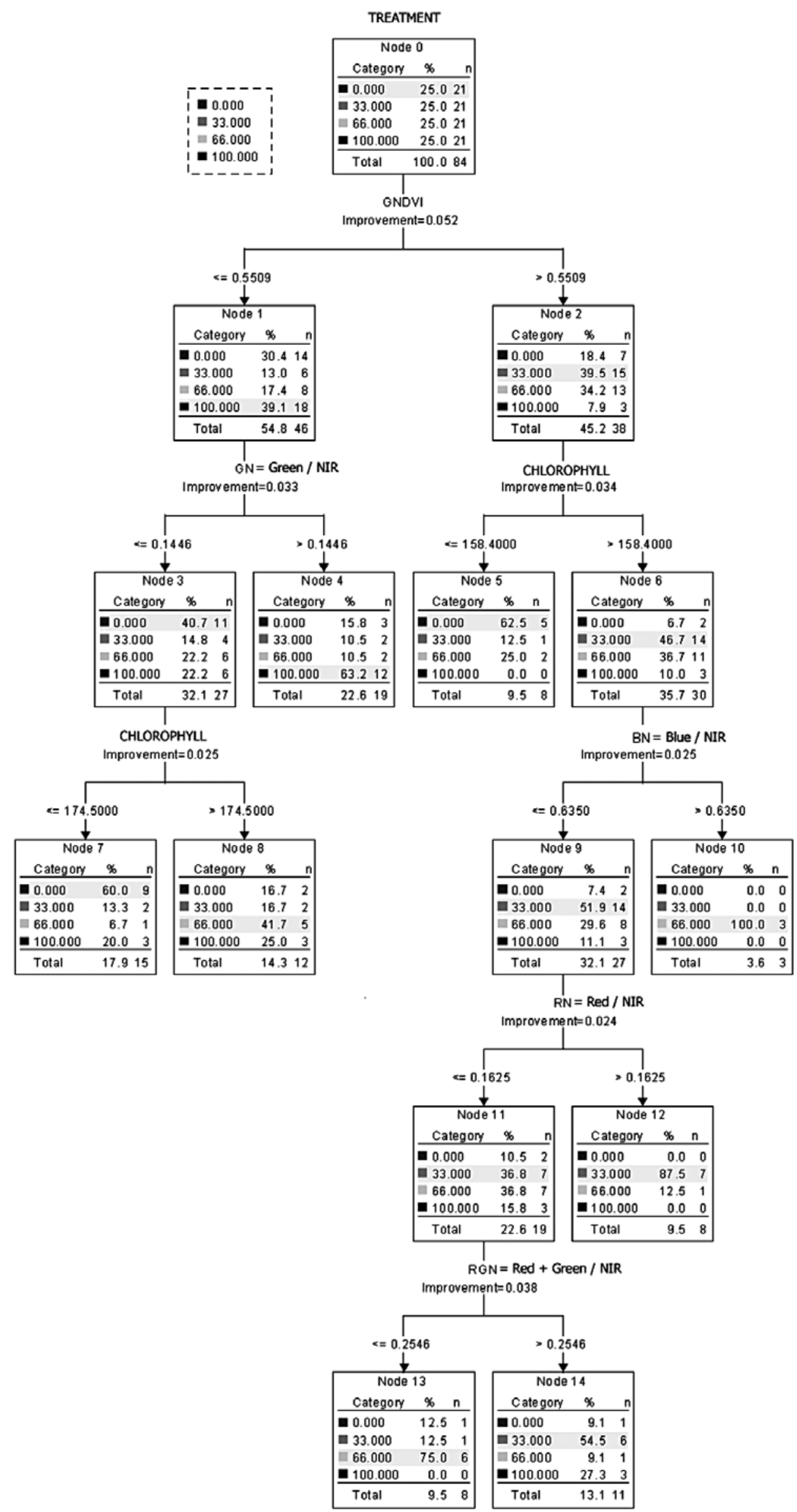

Figure 4. Classification tree for sweet corn exposed to four levels of water treatment before irrigation 


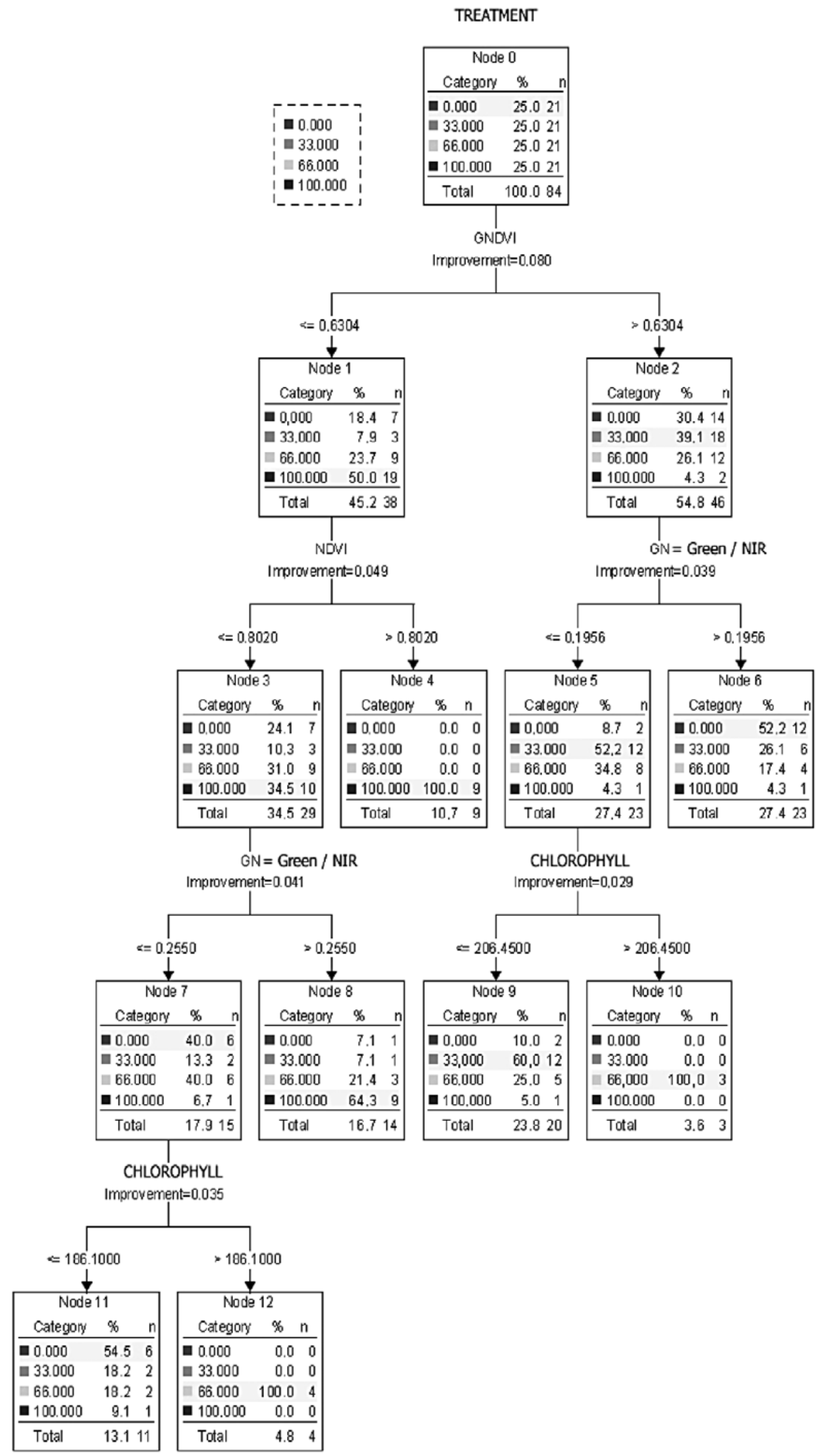

Figure 5. Classification tree for sweet corn exposed to four levels of water treatment after irrigation 
chlorophyll readings played a key role to determine water stress. When chlorophyll reading value was higher than 206.45 , severe water stress could be projected in $100 \%$ of plants $(66 \%$ PC). Furthermore, there was a moderate water stress in $60 \%$ of plants while chlorophyll value was smaller or equal to 206.45 (Fig. 5).

Presence of any stressor in plant species, either biotic or abiotic, is known to alter spectral properties of infected tissue. Reflectance properties of plants depend in part on the amount of water stored in the leaf cells, in particular in the NIR (Rodríguez-Pérez et al., 2007; Govender et al., 2009). For water sensitive regions of the spectrum, leaf and canopy reflectance decreases with increasing leaf water content, while an opposite trend occurs for the insensitive spectrum (Rodríguez-Pérez et al., 2007). Water sensitive wavelengths were combined in various ways to develop vegetation indices in order to quantify water deficiency or drought. Detection and quantification of water stress using spectral vegetation indices may substantially improve stress monitoring and water management by overcoming some of the shortcomings of traditional methods such as time requirement, subjective measurements and sampling procedures (Rodríguez-Pérez et al., 2007; Elsayed et al., 2011). In our study, spectral vegetation indices derived from hyperspectral reflectance spectra were used in CT to assess water stress in corn plants. Overall success rate of classification accuracy between predicted and measured values of stressed corn indicated that GNDVI has potential to determine water stress. Delalieux et al. (2007) used hyperspectral data in tree-based classification to detect disease in apple (Malus spp.) leaves and concluded that hyperspectral reflectance spectra were able to determine disease incidence in apple leaves. The advantage of tree-based classification includes that it does not require the assumption of probability distribution, specific interactions can be detected without previous inclusion in the model, nonhomogeneity can be taken into account, mixed data types can be used and dimension reduction of hyperspectral datasets is facilitated (Delalieux et al., 2007).

In addition, Goel et al. (2003) indicated that another benefit with decision tree is the formulation of simple and clear classification rules. The author reported that misclassification rates were $22 \%$ for nitrogen stress determination in corn using hyperspectral data. The same authors indicated that decision tree classification methods of hyperspectral data have potential for crop condition assessment.

\section{Conclusion}

We tested the ability of classification tree algorithm to assess water stress in corn using hyperspectral reflectance spectra transformed into spectral vegetation indices. The results of this study demonstrated that water stress in corn was detectable through spectral reflectance analysis. Water stress levels applied in this study clearly caused variation in the spectral reflectance and chlorophyll reading before and after irrigation. Chlorophyll readings and spectral reflectance that measured from crops before and after irrigation have potential to understand water stress in detail. It was found that the most effective index to determine water stress using classification tree (CT) model was green normalized difference vegetation index (GNDVI) for sweet corn.

\section{Acknowledgements}

We appreciate the constructive suggestions of all anonymous reviewers. Authors also thank Dr. Hakan Turhan, Çanakkale Onsekiz Mart University, for his suggestions on the experimental design.

Received 05062012

Accepted 04122012

\section{References}

Alberte R. S., Thornber J. P., Fiscus E. L. 1977. Water stress effects on the content and organization of chlorophyll in mesophyll and bundle sheath chloroplasts of maize. Plant Physiology, 59: 351-353

http://dx.doi.org/10.1104/pp.59.3.351

Blackburn G. A. 2007. Hyperspectral remote sensing of plant pigments. Journal of Experimental Botany, 58: 855-867 http://dx.doi.org/10.1093/jxb/erl123

Camdeviren H., Mendes M., Ozkan M. M., Toros F., Sasmaz T., Oner S. 2005. Determination of depression risk factors. Children and aolescents by regression tree methodology. Acta Medica Okayama, 59: 19-26

Chen J., Lin L., Lü G. 2010 (b). An index of soil drought intensity and degree: an application on corn and a comparison with CWSI. Agricultural Water Management, 97: 865-871 http://dx.doi.org/10.1016/j.agwat.2010.01.017

Chen P., Haboudane D., Tremblay N., Wang J., Vigneault P., Li B. 2010 (a). New spectral indicator assessing the efficiency of crop nitrogen treatment in corn and wheat. Remote Sensing of Environment, 114: 1987-1997 http://dx.doi.org/10.1016/j.rse.2010.04.006

Delalieux S., Van Aardt J., Keulemans W., Schrevens E., Coppin P. 2007. Detection of biotic stress (Venturia inaequalis) in apple trees using hyperspectral data: nonparametric statistical approaches and physiological implications. European Journal of Agronomy, 27: 130-143 http://dx.doi.org/10.1016/j.eja.2007.02.005

Elmetwalli A. M. H., Tyler A. N., Hunter P. D., Salt C. A. 2012. Detecting and distinguishing moisture- and salinity-induced stress in wheat and maize through in situ spectroradiometry measurements. Remote Sensing Letters, 3: 363-372 http://dx.doi.org/10.1080/01431161.2011.599346

Elsayed S., Mistele B., Schmidhalter U. 2011. Can changes in leaf water potential be assessed spectrally? Functional Plant Biology, 38: 523-533

Fensholt R., Sandholt I. 2003. Derivation of a shortwave infrared water stress index from MODIS near- and shortwave infrared data in a semiarid environment. Remote Sensing of Environment, 87: 111-121

http://dx.doi.org/10.1016/j.rse.2003.07.002 
Gao B. C. 1995. NDWI - a normalized difference water index for remote sensing of vegetation liquid water from space. Remote Sensing of Environment, 58: 257-266 http://dx.doi.org/10.1016/S0034-4257(96)00067-3

Genc L. 2003. Comparison of landsat MSS and TM imagery for long term forest land cover change assessment: $\mathrm{PhD}$ dissertation University of Florida. USA, 135 p.

Gitelson A. A., Merzlyak N. 1996. Signature analysis of leaf reflectance spectra: algorithm development for remote sensing of chlorophyll. Journal of Plant Physiology, 148: $494-500$ http://dx.doi.org/10.1016/S0176-1617(96)80284-7

Goel P. K., Prasher S. O., Patel R. M., Landry J. A., Bonnell R. B., Viau A. A. 2003. Classification of hyperspectral data by decision trees and artificial neural networks to identify weed stress and nitrogen status of corn. Computers and Electronics in Agriculture, 39: 67-93 http://dx.doi.org/10.1016/S0168-1699(03)00020-6

Govender M., Dye P. J., Weiersbye I. M., Witkowski E. T. F., Ahmed F. 2009. Review of commonly used remote sensing and ground-based technologies to measure plant water stress. Water SA, 35: 741-752 http://dx.doi.org/10.4314/wsa.v35i5.49201

Hunt E. R., Rock B. N. 1989. Detection of changes in leaf water content using near- and middle-infrared reflectance. Remote Sensing of Environment, 30: 43-54 http://dx.doi.org/10.1016/0034-4257(89)90046-1

Jordan C. F. 1969. Derivation of leaf area index from quality of light on the forest floor. Ecology, 50: 663-666 http://dx.doi.org/10.2307/1936256

Köksal E. S. 2011. Hyperspectral reflectance data processing through cluster and principal component analysis for estimating irrigation and yield related indicators. Agricultural Water Management, 98: 1317-1328 http://dx.doi.org/10.1016/j.agwat.2011.03.014

Lewis R. 2000. An introduction to classification and regression tree (CART) analysis. Academic Emergency Medicine. California, USA, p. 1-14

Mirik M., Michels G. J. Jr., Kassymzhanova-Mirik S., Elliott N. C., Bowling R. 2006. Hyperspectral spectrometry as a means to differentiate uninfested and infested winter wheat by greenbug (Hemiptera: Aphididae). Journal of Economic Entomology, 99: 1682-1690

http://dx.doi.org/10.1603/0022-0493-99.5.1682

Mirik M., Ansley R. J., Michels Jr. G. J., Elliott N. C. 2012. Spectral vegetation indices selected for quantifying Russian wheat aphid (Diuraphis noxia) feeding damage in wheat (Triticum aestivum L.). Precision Agriculture, 13: 501-516 http://dx.doi.org/10.1007/s11119-012-9264-7

O’Shaughnessy S. A., Evett S. R., Colaizzi P. D., Howell T. A. 2011. Using radiation thermography and thermometry to evaluate crop water stress in soybean and cotton. Agricultural Water Management, 98: 1523-1535 http://dx.doi.org/10.1016/j.agwat.2011.05.005

Ozdogan M. 2011. Modeling the impacts of climate change on wheat yields in northwestern Turkey. Agriculture, Ecosystems and Environment, 141: 1-12 http://dx.doi.org/10.1016/j.agee.2011.02.001

Padilla F. L. M., González-Dugo M. P., Gavilán P., Domínguez J. 2011. Integration of vegetation indices into a water balance model to estimate evapotranspiration of wheat and corn. Hydrology and Earth System Sciences, 15: 1213-1225 http://dx.doi.org/10.5194/hess-15-1213-2011

Peñuelas J., Fililla I., Biel C., Serrano L., Save R. 1993. The reflectance at the $950-970 \mathrm{~mm}$ region as an indicator of plant water status. International Journal of Remote Sensing, 14: 1887-1905 http://dx.doi.org/10.1080/01431169308954010

Rock B. N., Vogelmann J. E., Williams D. L., Vogelmann A. F., Hoshizaki T. 1986. Remote detection of forest damage. BioScience, 36: 439-445 http://dx.doi.org/10.2307/1310339

Rodríguez-Pérez J. R., Riaño D., Carlisle E., Ustin S., Smart D.R. 2007. Evaluation of hyperspectral reflectance indexes to detect grapevine water status in vineyards. American Journal of Enology and Viticulture, 58: 302-317

Rouse J. W., Haas R. H., Schell J. A., Deering D. W. 1973. Monitoring vegetation systems in the Great Plains with ERTS: $3^{\text {rd }}$ ERTS symposium. NASA, SP-351, 1: 309-317

Serrano L., Fillella I., Peñuelas J. 2000. Remote sensing of biomass and yield of winter wheat under different nitrogen supplies. Crop Science, 40: 723-731 http://dx.doi.org/10.2135/cropsci2000.403723x

Sims D. A., Gamon J. A. 2002. Estimation of vegetation water content and photosynthetic tissue area from spectral reflectance: a comparison of indices based on liquid water and chlorophyll absorption features. Remote Sensing of Environment, 84: 526-537 http://dx.doi.org/10.1016/S0034-4257(02)00151-7

Wang J. H., Geng L. H., Zhang C. M. 2012. Research on the weak signal detecting technique for crop water stress based on wavelet denoising. Advanced Materials Research, 424425: 966-970 http://dx.doi.org/10.4028/www.scientific. net/AMR.424-425.966

Weber V. S., Araus J. L., Cairns J. E., Sanchez C., Melchinger A. E., Orsini E. 2012. Prediction of grain yield using reflectance spectra of canopy and leaves in maize plants grown under different water regimes. Field Crops Research, 128: $82-90$

http://dx.doi.org/10.1016/j.fcr.2011.12.016

Yohannes Y., Hoddinott J. 1999. Classification and regression trees: an introduction. $<$ http://www.ifpri.org/sites/default/ files/ pubs/themes/mp18/techguid/tg03.pdf $>$ [accessed $01062012]$ 
ISSN 1392-3196

Zemdirbyste-Agriculture, vol. 100, No. 1 (2013), p. 81-90

UDK 633.15:631.67:520.84 / DOI 10.13080/z-a.2013.100.011

\title{
Paprastojo kukurūzo (Zea mays L.) drègmės streso nustatymas, taikant spektrinị atspindị ir klasifikavimo medžio metodą
}

\author{
L. Genc ${ }^{1}$, M. Inalpulat ${ }^{1}$, U. Kizil ${ }^{1}$, M. Mirik ${ }^{2}$, S. E. Smith ${ }^{3}$, M. Mendes ${ }^{1}$
}

${ }^{1}$ Canakkale Onsekiz Mart universitetas, Turkija

${ }^{2}$ Teksaso A\&M universiteto AgriLife tyrimų ir konsultavimo centras, JAV

${ }^{3}$ Floridos universitetas, JAV

\begin{abstract}
Santrauka
Drègmès stresas yra vienas svarbiausių augimą ribojančių veiksnių augalininkystėje. Siekiant nustatyti drègmės streso poveikį augalams, taikoma keletas metodų. Nustatant drègmès stresą itin tinkamu ir praktišku laikomas nuotolinių jutiklių metodas. Jị tinkamai taikant yra svarbių pranašumų, palyginus su drègmès streso nustatymu antžeminio stebėjimo būdu, pavyzdžiui, pakartojamumas, tikslumas, išlaidų efektyvumas. Tyrimo tikslai: 1) nustatyti drègmès streso įtaką paprastajam kukurūzui (Zea mays L.), taikant spektrinių rodiklių ir chlorofilo kiekio duomenis; 2) įvertinti atspindžio spektrus pagal klasifikavimo medžio metodą, siekiant nustatyti drègmės streso lygį. Kukurūzų spektriniai ir chlorofilo matavimai buvo atlikti prieš kiekvieną laistymą ir po jo taikant keturis drègmės streso lygius: $0,33,66$ ir $100 \%$ vegetacinio indo drègmès imlumo. Tyrimo rezultatai parodè, kad didinant lauko vandens imlumo lygi, atspindys raudonojoje (600-700 nm) elektromagnetinio spektro dalyje sumažejo, o artimoje infraraudonajai dalyje (700-900 nm) padidejo. Prieš drèkinimą pamatuotas atspindys dažniausiai buvo didesnis, palyginus su po drèkinimo artimoje infraraudonajai dalyje, ir mažesnis raudonojoje dalyje. Tačiau palyginus vien tik keturis vegetacinio indo vandens imlumo lygius prieš ir po drẻkinimo, atspindžio spektrai parodè, kad kukurūzu augalai, patiriantys drègmès stresą, sugèrè mažiau šviesos matomojoje ir daugiau šviesos artimai infraraudonajai spektro dalyse, palyginus su mažiau streso patiriančiais ir jo nepatiriančiais augalais. Panaši drègmės streso lygių išraiškos tendencija nustatyta naudojant chlorofilo matuoklio duomenis, kurie tyrimo metu mažèjo. Klasifikavimo medžio analizès rezultatai atskleidè, kad drègmès stresą ir jo lygi galima nustatyti naudojant chlorofilo matuoklio ir atspindžio duomenis, juos pavertus ị spektrinius augmenijos rodiklius.
\end{abstract}

Reikšminiai žodžiai: drègmès stresas, klasifikavimo medis, spektrinis atspindys, Zea mays. 